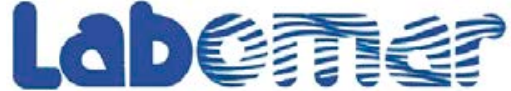

Arquivos de Ciências do Mar

\section{RAINFALL SEASONAL VARIATION EFFECT ON THE REPRODUCTIVE CYCLE OF THE BIVALVE Phacoides pectinatus FROM SEMIARID COAST OF BRAZIL}

\section{Efeito da variação sazonal da precipitação no ciclo reprodutivo do bivalve Phacoides pectinatus na costa semiárida do Brasil}

\author{
Lígia Maria Borges Marques Santana ${ }^{1}$, Cristina de Almeida Rocha-Barreira ${ }^{*}$ \\ ${ }^{1}$ Pós-Graduação em Ecologia e Recursos Naturais, Universidade Federal do Ceará. \\ ${ }^{2}$ Instituto de Ciências do Mar, Universidade Federal do Ceará, Fortaleza Brazil. Laboratório de Zoobentos, \\ Instituto de Ciências do Mar, Av. da Abolição 3207, Praia do Meireles 60165-081, Fortaleza, CE, Brasil. \\ *Author for correspondence: cristina.labomar@gmail.com
}

\begin{abstract}
This study tested the hypothesis that the reproductive cycle of bivalve Phacoides pectinatus from Ceará river estuary, at semiarid coast of Brazil, is influenced by rainfall and dry seasonal variations. Thus, the seasonality of gonadal development stages of P. pectinatus was evaluated by histological analyzes of the gonads and correlated with temporal variations of temperature, salinity, and local rainfall. Specimens $(>8 \mathrm{~mm})$ were collected monthly from April 2008 to September 2009. Four stages of gonadal development were identified. A total of 366 specimens were analyzed and measured between $8.93 \mathrm{~mm}$ and $68.5 \mathrm{~mm}$ of total shell length. The $P$. pectinatus population in the Ceará river estuary presented a 1:1 sexual ratio with continuous reproduction, strongly conditioned by precipitation and salinity variations. The gametogenesis was predominant in February to May (rainy season) and the ripe and spawning occurs in July to December (dry period). The increased rainfall with the consequent decrease in salinity act as natural disturbance in the estuary, on an annual rate, contributing to the renewal of the population.
\end{abstract}

Keywords: gonadal development; rainfall; estuary

Recebido em: 01/11/2018

Aprovado em: 30/12/2018

Publicado online em: 25/03/2019 


\section{RESUMO}

Este estudo testou a hipótese de que o ciclo reprodutivo da bivalve Phacoides pectinatus do estuário do rio Ceará, no litoral semiárido do Brasil, é influenciado pelas variações sazonais de precipitação. Assim, a sazonalidade dos estágios de desenvolvimento gonadal de P. pectinatus foi avaliada por análises histológicas das gônadas e correlacionada com variações temporais de temperatura, salinidade e precipitação locais. Exemplares adultos foram coletados mensalmente de abril de 2008 a setembro de 2009, totalizando 366 indivíduos apresentando entre 8,93 mm e 68,5 $\mathrm{mm}$ de comprimento total de concha. Foram identificados quatro estágios de desenvolvimento gonadal. A população de P. pectinatus no estuário do rio Ceará apresentou razão sexual de 1:1, com reprodução contínua, fortemente condicionada por variações de precipitação e salinidade. A gametogênese foi predominante em fevereiro a maio (período chuvoso) e o estado maturo e a liberação de gametas ocorreram de julho a dezembro (período seco). O aumento das chuvas, com a consequente diminuição da salinidade, agem como perturbação natural no estuário, a uma taxa anual, contribuindo para a renovação da população.

Palavras-chave: desenvolvimento gonadal; precipitação; estuário.

\section{INTRODUCTION}

Estuaries on tropical semi-arid coasts tend to reflect the conditions of the river basin and show a strong seasonal pattern determined by short, but intense, periods of rainfall (precipitation $<50 \mathrm{~mm}$ in the dry season and $>400 \mathrm{~mm}$ in the rainy season) (Barletta \& Costa, 2009). This sparse and variable precipitation of arid and semi-arid regions is believed to exert strong control over the life histories, physiological characteristics, and species composition of their biota (Chesson et al., 2004). This fact suggests that the variable rainfall distribution in tropical estuaries acts as a natural disturbance, closely related to the maintenance of organisms in the habitat. Environmental characteristics are essentials on the life history of organisms, reflecting on reproductive behavior that establishes reproduction patterns (Fenchel, 1987). Although identical individuals can have different life strategies at different habitats, natural selection tends to maximize the adaptive value (fitness) of each individual, optimizing the offspring number that reach maturity (Rodhouse et al., 1988).

The study of the gonadal development is essential to understand the reproductive biology of any organism, improving the knowledge of the ecological aspects of the species (Narchi, 1976). The histological examination of the gonads is used to describe the gametogenic cycle (Power et al., 2004) and allows analyzing the changes and transitions during the gonadal tissue growth according to the environmental variations, which may be related to population attributes.

Phacoides pectinatus (Gmelin, 1791) is a Lucinidae bivalve commonly exploited on Brazilian coast mangrove for supplement food and handicrafts. This species can be found from North Carolina, USA, to Santa Catarina, southern Brazil (Rios, 2009). Despite the commercial importance, as many other species of molluscs in Brazil, there are few studies of basic information regarding its occurrence and conservation status. Studies on the biology and adaptations of the species are therefore fundamental to understanding the 
evolution of natural history characteristics to survival (Stearns, 1992). It is an important starting point for decision-making in monitoring, management and conservation of biota, including molluscs, since they make it possible to predict recruitment and spawning times (Power et al., 2004) and provide insights into the structure and dynamics of the exploited populations and their relationships with the environment in which they live.

This study tested the hypothesis that the reproductive cycle of bivalve Phacoides pectinatus, from Ceará river estuary, at semiarid coast of Brazil, is influenced by seasonal variations in rainfall and dry. Thus, the seasonality of gonadal development stages of $P$. pectinatus was evaluated by histological analyzes of the gonads and correlated with temporal variations of temperature, salinity, and local rainfall.

\section{MATERIALS AND METHODS}

\section{Study site and animal collection}

The individuals of $P$. pectinatus were collected in Ceará river estuary, Ceará State,

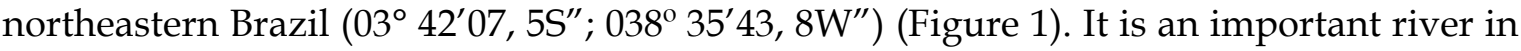
the metropolitan region of Fortaleza, on the west side of the city with a high human population density and serious environmental impacts, caused by intensive and continuous industrial and domestic contamination (Aguiar et al., 2004; Marins et al., 2004; Vaisman et al., 2005).

Approximately 20 animals were taken monthly from April 2008 to September 2009, during low tide. The animals were removed from the sediment at approximately $20 \mathrm{~cm}$ depth with the aid of a gardening shovel. Temperature (of the air, the sediment percolation water and the estuary water) and salinity (of the sediment percolation water and the estuary water) were measured using YSI - 556 MPS (Multi Probe System). Rainfall data from this period were obtained monthly from the website of the Ceará Foundation of Meteorology and Water Management (FUNCEME) (http://www.funceme.br). Animals were transported in plastic pots with water from the local to the Zoobentos Laboratory, Instituto de Ciências do Mar, Universidade Federal do Ceará.

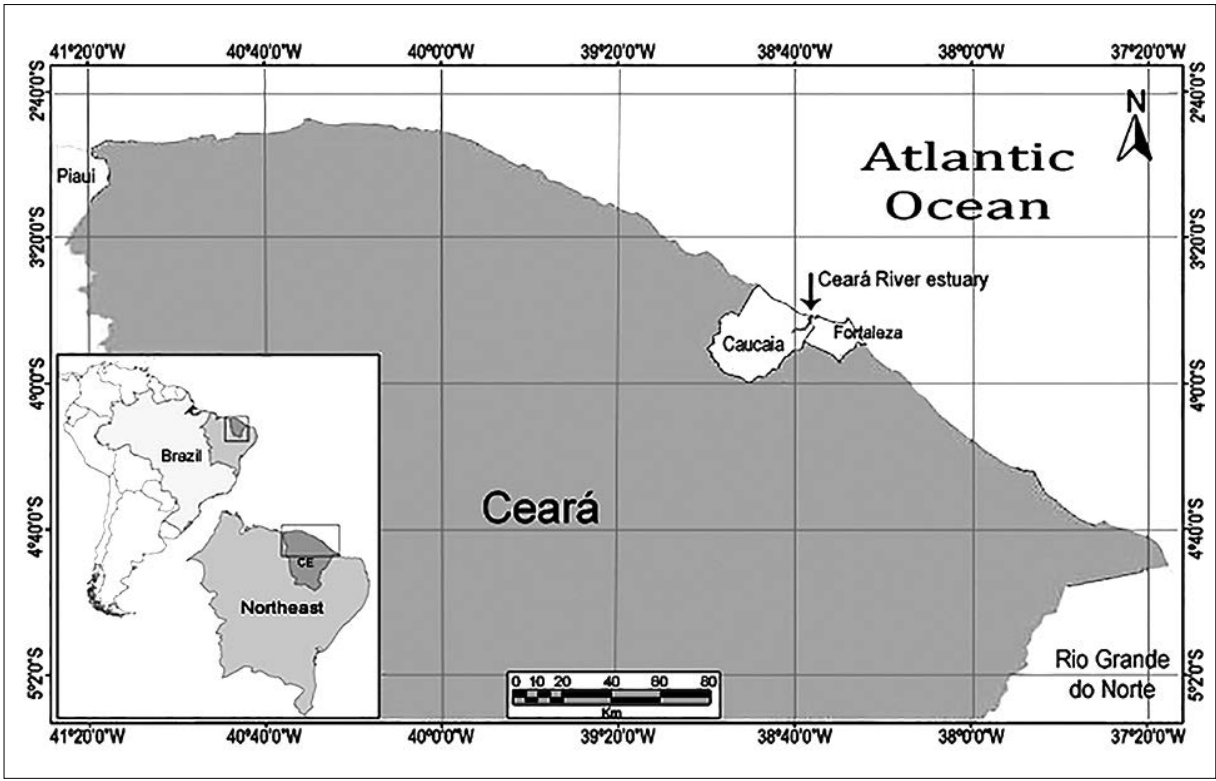

Figure 1 - Location of study site at Ceará river estuary, Fortaleza, Ceará, Brazil $\left(03^{\circ} 42^{\prime} 07,5^{\prime \prime} \mathrm{S}\right.$ $\left.038^{\circ} 35^{\prime} 43,8^{\prime \prime} \mathrm{W}\right)$. 


\section{Biometry and Histological analysis}

At the laboratory, each animal was measured on the antero-posterior axis (length) using a caliper precision $0.05 \mathrm{~mm}$. Shell and soft parts content of animals were weighed (W) still fresh with a precision scale, and the condition index (CI) calculated according to Lucas \& Beninger (1985) as follows: CI = Wsoft parts / Wshell X 100.

Gonad was fixed in Bouin's solution for 16 hours and kept in 70\% alcohol until histological processing. The histological processing followed the routine procedures, through a series of dehydration in alcohol, cleared in xylen and embedded in paraffin. Cross sections of $5 \mu \mathrm{m}$ thickness were stained with Harris'hematoxylin and $1 \%$ aqueaus eosin (H\&E), and analyzed by optical microscope Standard 25, Zeiss.

\section{Determination of sex and reproductive stage}

Definitions of the gonadal development stages were adapted from earlier studies (Assis, 1985; Darriba et al., 2004; Farias \& Rocha-Barreira, 2017) (Table 1, Figures 2 and 3). The characterization of stages of gonadal development was carried out by the predominance of germ cells and by the general appearance of the gonad of each individual analyzed.

Table 1 - Description of gonadal developmental stages assigned to male and female Phacoides pectinatus.

\begin{tabular}{|c|c|c|}
\hline Stages & Male & Female \\
\hline $\begin{array}{l}\text { Stage zero }(0) \\
\text { Immature, } \\
\text { undifferentiated }\end{array}$ & \multicolumn{2}{|c|}{$\begin{array}{l}\text { Sexual differentiation is not possible. Small, isolated follicles at the beginning of cell organization, } \\
\text { with large acidophilic cells, with diffuse cytoplasm and non-condensed nucleus. (Figure 2A). }\end{array}$} \\
\hline $\begin{array}{l}\text { Stage I - Initial } \\
\text { gametogenesis }\end{array}$ & $\begin{array}{l}\text { Spermatogenesis begins, differentiating } \\
\text { spermatogonia, spermatocytes I, } \\
\text { spermatocytes II, spermatids and early } \\
\text { spermatozoids (Figure 2B and 2C). }\end{array}$ & $\begin{array}{l}\text { Pre-vitellogenic oocytes characterized by oval or } \\
\text { pyriform cells, with a slightly acidophilic } \\
\text { cytoplasm and a large nucleus with two } \\
\text { basophilic accessory nucleoli close to the nuclear } \\
\text { membrane (Figure 3A and 3B). }\end{array}$ \\
\hline $\begin{array}{l}\text { Stage II - Advanced } \\
\text { gametogenesis }\end{array}$ & $\begin{array}{l}\text { The follicles completely filled, with germ } \\
\text { cells in all phases, but with predominance } \\
\text { of initial cells (Figure 2D).Sperm are } \\
\text { arranged radially with a tail toward the } \\
\text { lumen of the follicle. }\end{array}$ & $\begin{array}{l}\text { Pedunculated vitellogenic oocytes attached to } \\
\text { the follicle wall or free in the lumen and free } \\
\text { mature oocytes in the center of the follicle exhibit } \\
\text { differentiated membrane (Figure } 3 C \text { ). }\end{array}$ \\
\hline $\begin{array}{l}\text { Stage III - Sexual } \\
\text { maturity: IIIA - Ripe }\end{array}$ & $\begin{array}{l}\text { Spermatozoa occupy the lumen of the } \\
\text { follicle, much larger than the other germ } \\
\text { cells (Figure 2E). }\end{array}$ & $\begin{array}{l}\text { Mature oocytes, free in the lumen, polygonal due } \\
\text { to packaging, exhibit nuclei and characteristic } \\
\text { thickened membrane (Figure 3D). }\end{array}$ \\
\hline III B - Spawning & $\begin{array}{l}\text { Follicles lose their radial spermatozoa } \\
\text { arrangement, showing empty spaces } \\
\text { (Figure 2F). }\end{array}$ & $\begin{array}{l}\text { Follicles with empty spaces, with fewer mature } \\
\text { oocytes, rare pre-vitellogenic oocytes, } \\
\text { vitellogenic oocytes, and very thin follicular } \\
\text { walls (Figure 3E). }\end{array}$ \\
\hline $\begin{array}{l}\text { III C - Final } \\
\text { spawning, gonad } \\
\text { restoration: }\end{array}$ & $\begin{array}{l}\text { The follicles decrease considerably and } \\
\text { large intrafollicular spaces filled by } \\
\text { connective tissue are observed (Figure 2G). } \\
\text { Spermatocytes become more abundant. }\end{array}$ & $\begin{array}{l}\text { The wall of the follicles becomes thicker with } \\
\text { onset of vitellogenesis (Figure 3F). Pre- } \\
\text { vitellogenic oocytes are more abundant than the } \\
\text { other germ cells. }\end{array}$ \\
\hline $\begin{array}{c}\text { Stage IV - Cellular } \\
\text { atresia }\end{array}$ & $\begin{array}{l}\text { The follicles were disorganized, with no } \\
\text { intrafollicular space, and germ cells with } \\
\text { no defined developmental stages and } \\
\text { atresic aspect (Figure } 2 \mathrm{H} \text { ). }\end{array}$ & $\begin{array}{l}\text { The follicles were small and empty, with } \\
\text { considerable invasion of hemocytes inside and } \\
\text { outside the regenerating follicles, with a probable } \\
\text { phagocytic function (Figure } 3 \mathrm{G} \text { and } 3 \mathrm{H} \text { ). }\end{array}$ \\
\hline
\end{tabular}




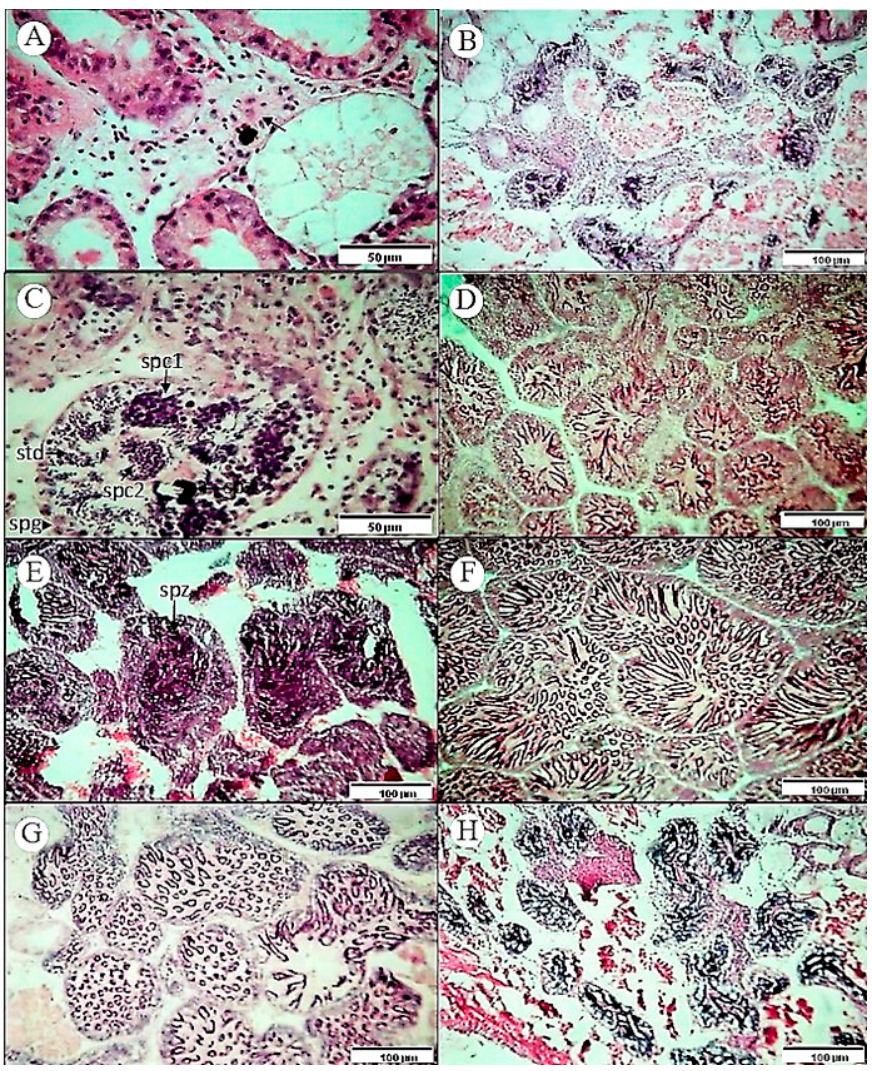

Figure 2 - Histological sections of male Phacoides pectinatus gonads. Male gonadal developments stages (H\&E). A) Stage 0 (imature) (arrow indicates undifferentiated germative cells). B) Stage I. C) Stage I detail. D) Stage II. (* indicates cell proliferation). E) Stage IIIA. F) Stage III B. G) Stage IIIC. H) Stage IV. Legend: spg = spermatogonia; spc1 = spermatocyte I; spc2 = spermatocyte II, std $=$ spermatid $; \mathrm{spz}=$ spermatozoa .

Figure 3 - Histological sections of male Phacoides pectinatus gonads. Female gonadal developments stages (H\&E). A) Stage I. B) Stage I detail, showing oogonia and pre-vitellogenic oocyte. C) Stage II ${ }^{*}$ indicates cell proliferation). D) Stage III A. E) Stage III B. F) Stage III C. G) Stage IV. H) Stage IV detail. Legend: og = oogonia; op = pre-vitellogenic oocyte, $\mathrm{fm}=$ follicular membrane; he $=$ hemocytes .

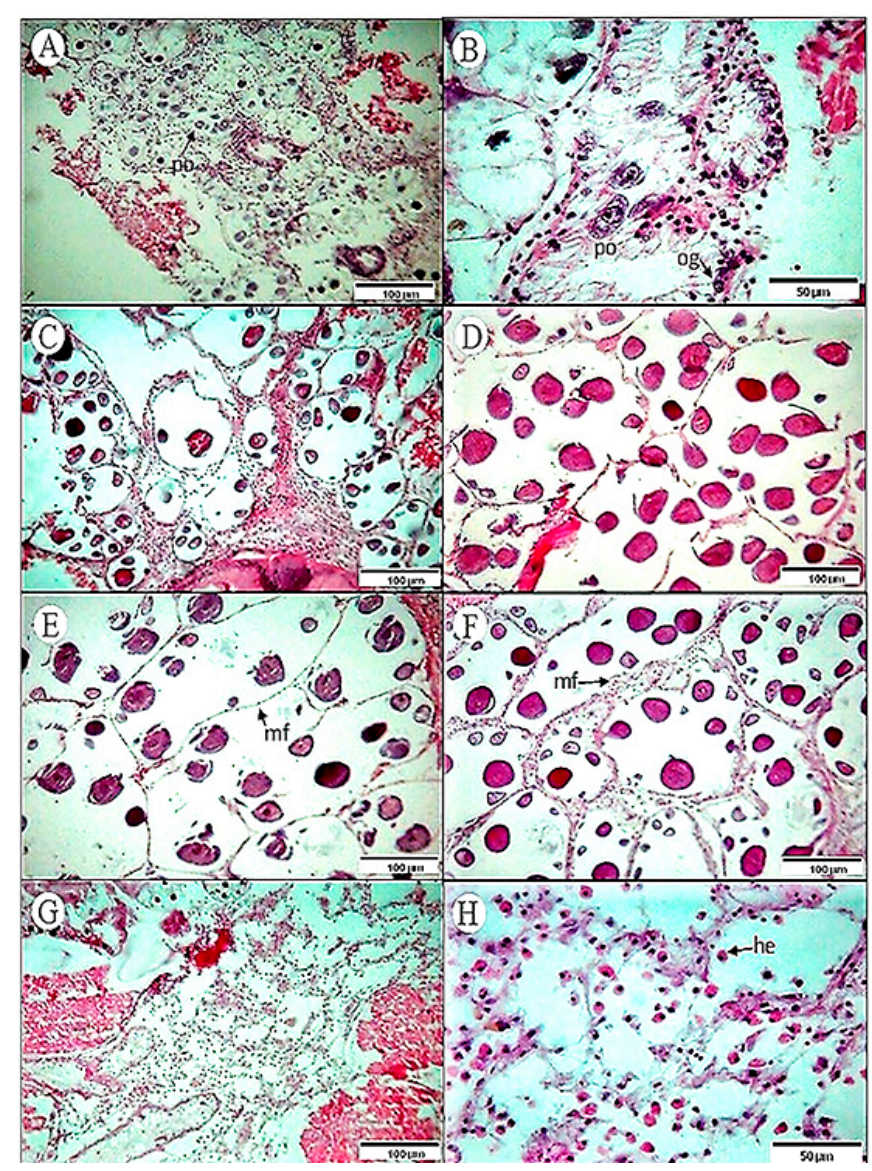




\section{Statistical analysis}

Temperature (air, sediment and water) data were submitted to the Kruskal-Wallis test for non-parametric data at a confidence interval of $5 \%$ to recognize the differences between the study months. Salinity (sediment and water) was submitted to analysis of variance (ANOVA) at a confidence interval of 5\%, considering the necessary premises (normality, homoscedasticity and independence). The average shell length and the average body weight of animals were also compared between the study months by Kruskal-Wallis test. The sex ratio for all months pooled was tested using the $\mathrm{X}^{2}$-test. The reproductive cycle was evaluated considering the monthly percentage of the gonadal development stages. A nonparametric Spearman rank correlation was used to assess relationships among the environmental variables and percentages of gonadal development stages. All statistical analysis were conducted using Statistica ${ }^{\circledR}$ version 7.0.

\section{RESULTS}

\section{Environmental parameters}

Temperature (air, sediment and water) ranged from $24.0^{\circ} \mathrm{C}$ to $35.7^{\circ} \mathrm{C}$, without significant difference between them (Kruskal-Wallis test: $\mathrm{H}(2, \mathrm{~N}=142)=4.27, \mathrm{p}=0.12$ ). Salinity varied significantly between the months (ANOVA one-way test: $\mathrm{N}_{\text {water }}=51, \mathrm{~F}=$ 631.70, $\mathrm{p}<0.00, \mathrm{~N}_{\text {sediment }}=48, \mathrm{~F}=65.61, \mathrm{p}<0.00$ ). The months with lower salinity (water and sediment) coincided with the 2008 and 2009 rainy periods (Spearman rank correlations $R_{\text {water }}=-0.72, R_{\text {sediment }}=-0.73, p<0.05$ ) (Figure 4). The FUNCEME considers that the rainy seasons in Ceará State correspond to the months in which accumulated precipitation exceeds $200 \mathrm{~mm}$. This study was initiated at the end of the rainy season 2008 (April 2008) and finished at the beginning of the dry season 2009 (September 2009). The rainy season of 2009 presented higher precipitation rates than expected for the period (normal cumulative precipitation calculated monthly by FUNCEME).

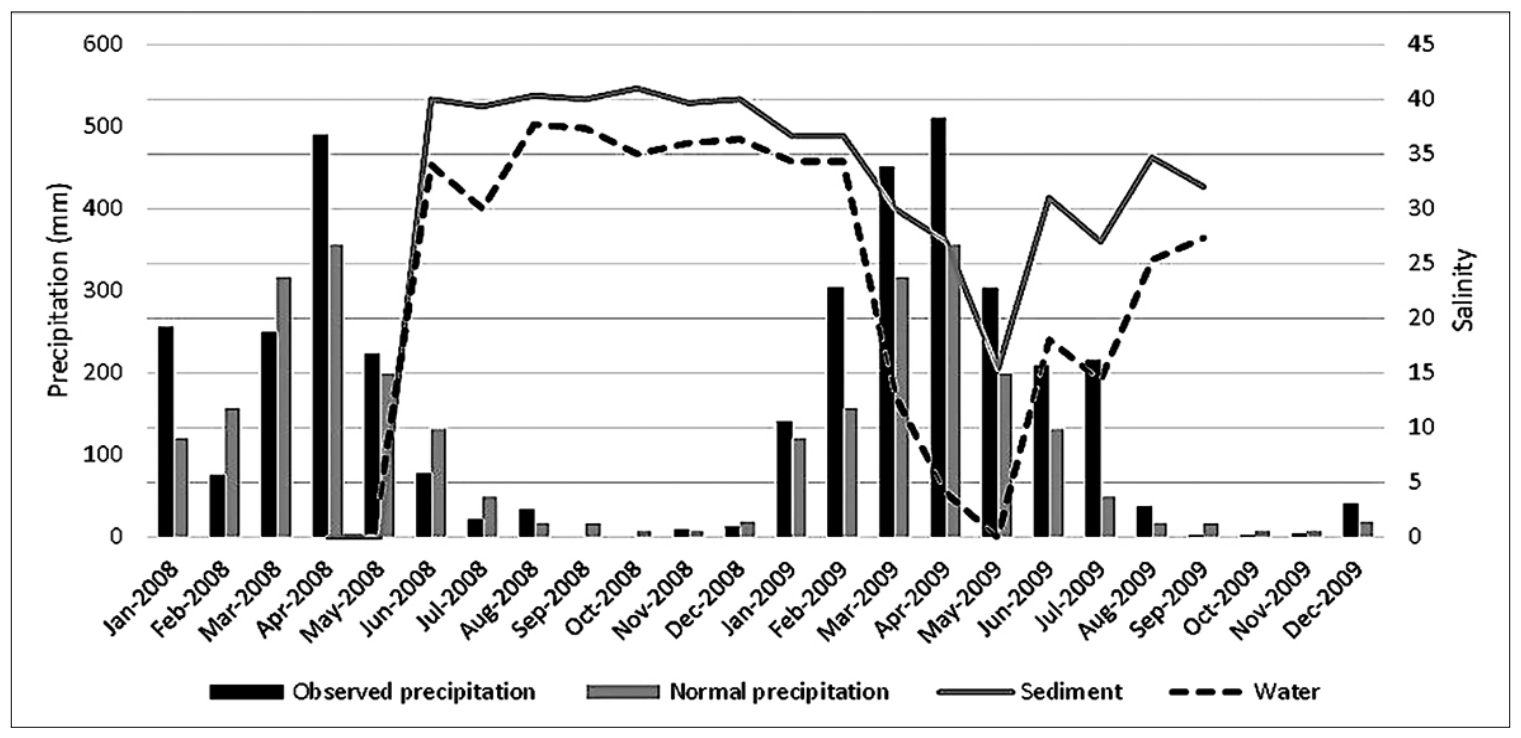

Figure 4 - Salinity (water and sediment) and normal and observed precipitation from April 2008 to September 2009 in the Ceará river estuary. Precipitation data provided by FUNCEME (Dashed lines represent extra periods of precipitation data for the area). 


\section{Sex ratio}

The individuals of $P$. pectinatus presented separated sex. The mature gonad has macroscopic difference, the male gonad is whitish and the female gonad is reddish. The sex of the animals was confirmed by histological examination. We analyzed 366 specimens, $5.2 \%$ were considered immature, $42.9 \%$ were males and $51.4 \%$ were females, and $0.5 \%$ could not be sexed because parasites infection. The ratio of males and females sampled was not significantly different $\left(x^{2}=1.39, p>0.05\right)$ from $1: 1$. Both males and females occurred in all months sampled, and no significant differences in their abundances. The largest percentage of males was found in June 2009 (68.8\%), followed by July 2008 (60\%). In October and November 2008, there were the fewest males, 31.3\% and 31.8\%, respectively. Females were more frequent in October 2008 (68.8\%), April 2009 (64.7\%) and September 2009 (64.7\%) and less frequently in July 2008 (30\%) and June 2009 (31.3\%). The immature individuals presented a low percentage and were absent in April, August and October 2008, and January, February, April, May, June and September 2009. Despite the low frequency over the months (5.2\%), the immature represented $23.5 \%$ of individuals collected in August 2009.

\section{Biometrics and Condition Index}

The analyzed animals measured between $8.93 \mathrm{~mm}$ and $68.5 \mathrm{~mm}$ of total length of the shell. The smaller sexed individuals had $13.6 \mathrm{~mm}$ of shell length. The highest mean length was recorded in June $2008(46.7 \pm 10.9 \mathrm{~mm}, \mathrm{n}=26)$, and the lowest mean length in August 2009 (32.06 $\pm 7.8 \mathrm{~mm}, \mathrm{n}=17)$. The highest mean body weight was in June 2008 (33.94 \pm 18.25 $\mathrm{g}, \mathrm{n}=26)$ and the lowest mean body weight was in June $2009(5.85 \pm 3.0 \mathrm{~g}, \mathrm{n}=16)$. The shell length (Kruskal-Wallis test: $\mathrm{H}(17, \mathrm{~N}=366)=115.6795 \mathrm{p}<0.05)$ and body weight of animals (Kruskal-Wallis test: H $(17, \mathrm{~N}=366)=114.8658 \mathrm{p}<0.05)$ were significantly lower from April 2008 to January 2009 (dry period) compared to February to May 2009 (rainy season). A second period of smaller organisms was observed between July and August 2009 (Figure 5 and Figure 6).

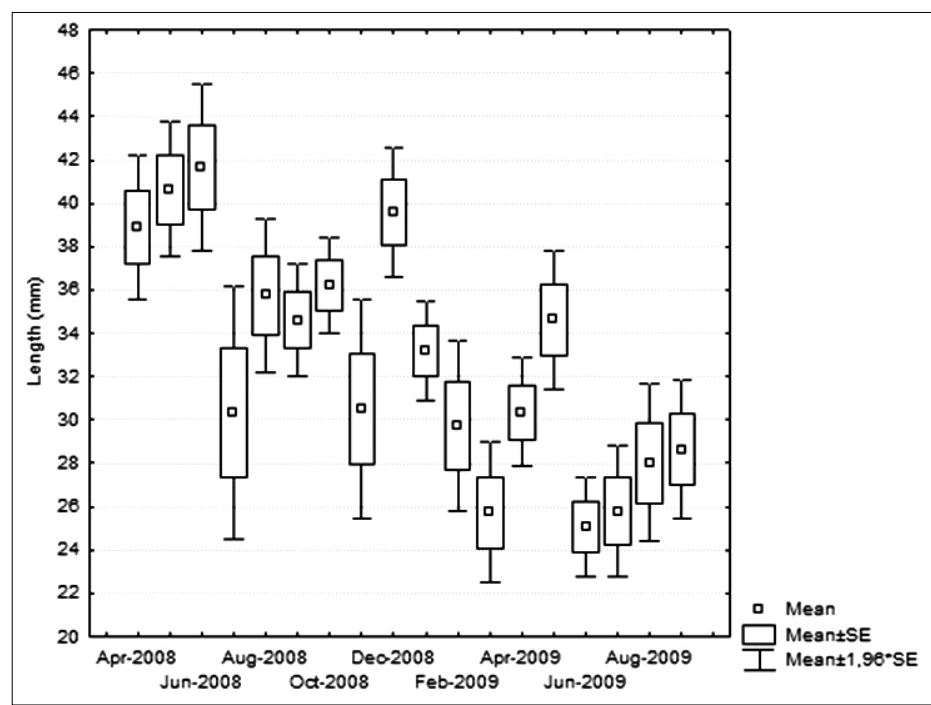

Figure 5 - The mean body length of Phacoides pectinatus captured from April 2008 to September 2009 in Ceará river estuary. 


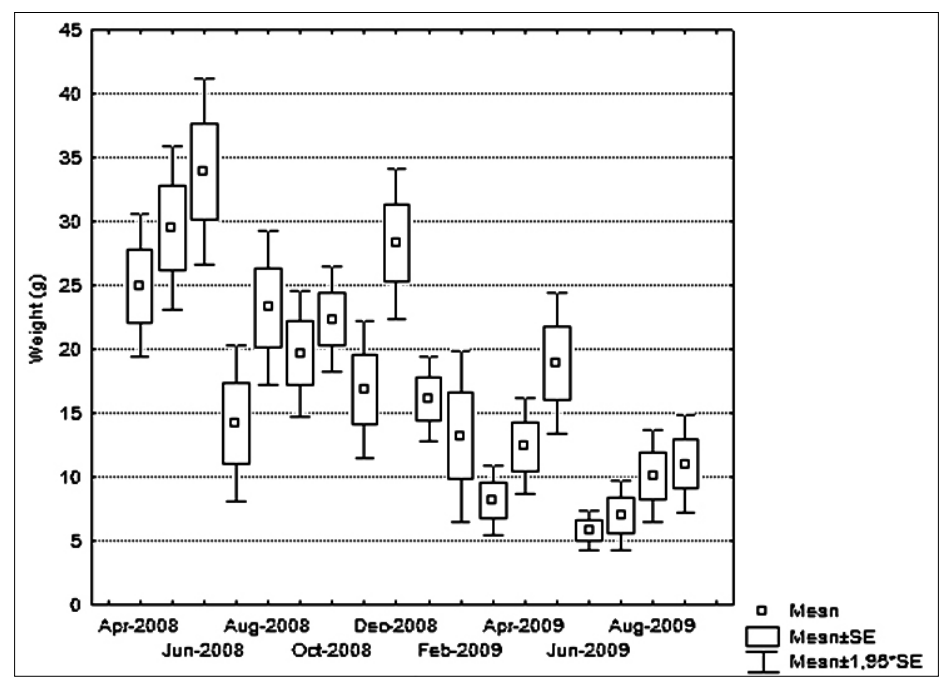

Figure 6 - The mean body weight of Phacoides pectinatus captured from April 2008 to September 2009 in Ceará river estuary.

The average monthly CI ranged from $16.26 \%$ to $77.88 \%$ for males and $15.86 \%$ to $76.07 \%$ for females. The Mann-Whitney U Test indicated a significant difference in the CI between sexes $(U=12348, p=0.008)$. When sexes were pooled, there was a significant difference in CI between months (Kruskal-Wallis test: $\mathrm{H}(16, \mathrm{~N}=346)=32.64061 \mathrm{p}=0.0082$ ). The average monthly CI indicate that smaller animals prevailing from February to May 2009 (rainy season) are healthier than larger individuals do predominantly from July to December 2008 (dry season).

\section{Gonadal development stages}

The gonad is lined by a thin connective tissue layer and is formed by follicles where the germinal cells are located. Some animals had gonads infested by digenian parasites, with disruption of the follicular walls and absence of the germ cells, sometimes preventing the sexing of animals.

Gonadal maturation of Phacoides pectinatus is a dynamic and continuous process. Gametogenesis stages (I + II), in both sexes, were less evident in 2008, but showed high percentages from May to July 2009 (rainy season) (Figure 7). A negative correlation between gametogenesis stages and salinity (sediment and water) were observed (Table 2). The maturation and spawning (IIIA + IIIB + IIIC) occurred in all months for both sexes, with predominance from July 2008 to February 2009 (majority in the dry period) (Figures 5 and 6). A positive correlation between these stages and sediment and water salinity was observed (Table 2). The males in cell atresia (IV) were observed in almost every month, mainly in April 2008 and April and August 2009 (Figure7). These results show a predominant cycle of gametogenesis and cellular atresia in February to May (rainy season) and gamete release in July to December (dry period) (Figures 7 and 8). 
Table 2 - Nonparametric Spearman's rank correlation between the percentage of gonadal development stages for males and females of Phacoides pectinatus captured from April 2008 to September 2009 in Ceará river estuary and the environmental variables (I + II = gametogenesis, IIIA+IIIB+IIIC = mature and spawn, IV = cellular atresia) [ ${ }^{*}$ significantly different values $(p<0.05)]$.

\begin{tabular}{lrrrrrr}
\hline & \multicolumn{6}{c}{ Gonadal development stages } \\
\cline { 2 - 7 } Environmental parameters & \multicolumn{5}{c}{ Males } & \multicolumn{5}{c}{ Females } \\
& I+II & IIIA+IIIB+IIIC & IV & I+II & IIIA+IIIB+IIIC & IV \\
\hline Precipitation $(\mathrm{mm})$ & 0.08 & $-0.55^{*}$ & 0.42 & 0.19 & -0.42 & -0.02 \\
Sediment temperature $\left({ }^{\circ} \mathrm{C}\right)$ & 0.23 & -0.07 & 0.02 & 0.07 & -0.16 & 0.15 \\
Water temperature $\left({ }^{\circ} \mathrm{C}\right)$ & -0.43 & 0.22 & 0.28 & -0.45 & 0.42 & 0.25 \\
Sediment salinity & $-0.50^{*}$ & $0.59^{*}$ & -0.10 & $-0.61^{*}$ & $0.67^{*}$ & 0.25 \\
Water salinity & -0.20 & $0.64^{*}$ & -0.34 & $-0.56^{*}$ & $0.59^{*}$ & 0.05 \\
\hline
\end{tabular}

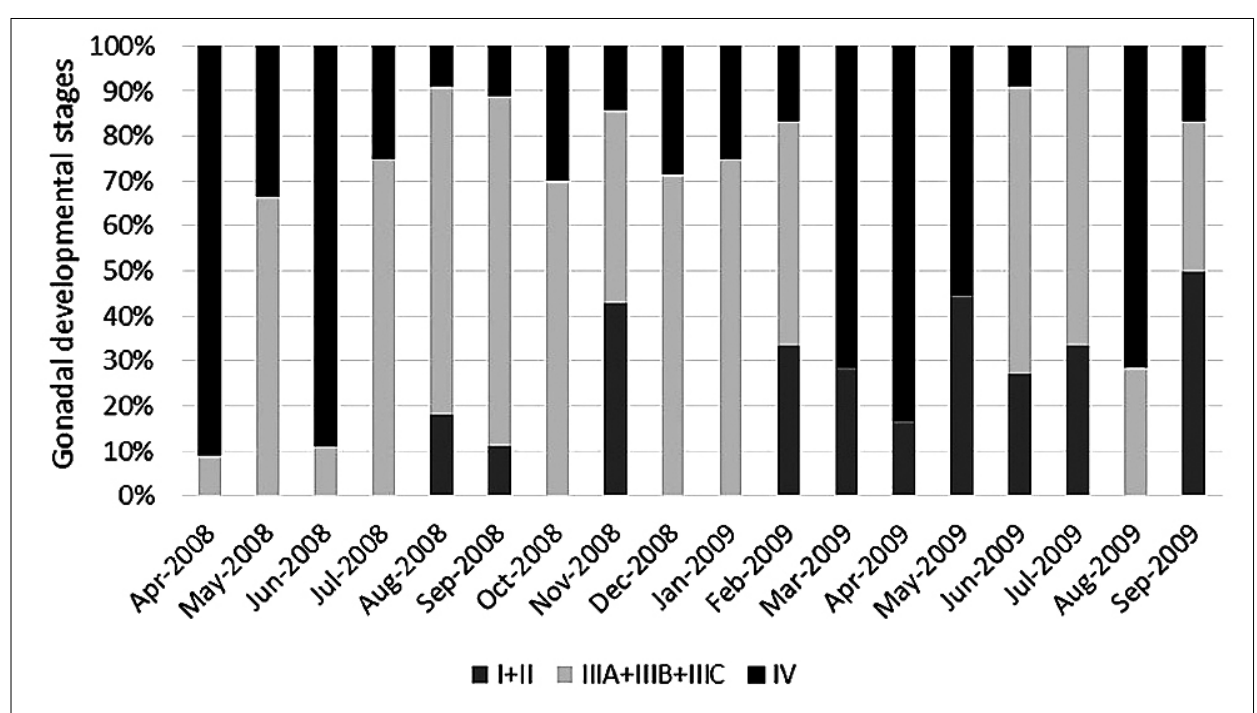

Figure 7-Monthly frequency of male gonadal development stages (I + II = gametogenesis, IIIA+IIIB+IIIC $=$ mature and spawn, IV = cellular atresia) of Phacoides pectinatus, captured from April 2008 to September 2009 in the Ceará river estuary.

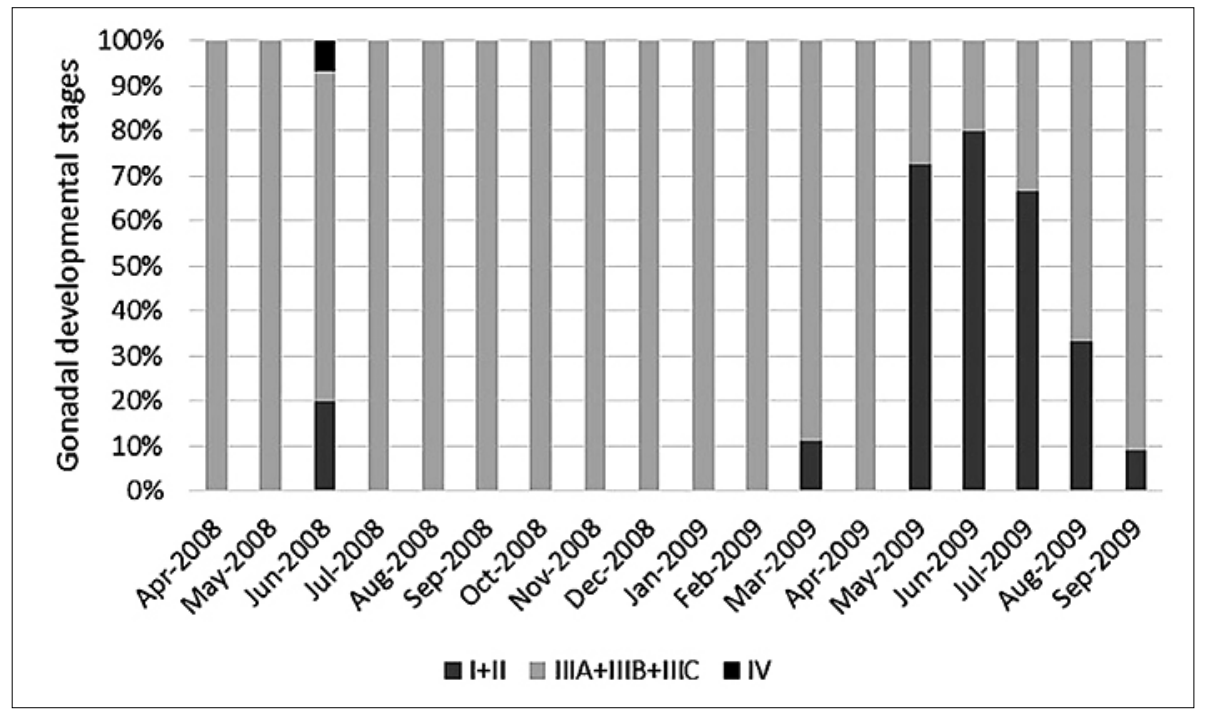

Figure 8 - Monthly frequency of female gonadal development stages (I + II = gametogenesis, IIIA+IIIB+IIIC = mature and spawn, IV = cellular atresia) of Phacoides pectinatus and salinity, captured from April 2008 to September 2009 in the Ceará river estuary. 


\section{DISCUSSION}

The Phacoides pectinatus population in the Ceará river estuary presented a 1:1 sexual ratio with continuous reproduction, strongly conditioned by precipitation and salinity variations. Several tropical bivalves presented continuous reproductive cycles, such as Amusium papyraceum (Gabb, 1873) (Penchaszadeh et al. 2000); Anadara ovalis (Bruguiere, 1789) (Power et al. 2004); Crassostrea virginica (Cárdenas et al., 2007); Anomalocardia flexuosa (Linnaeus, 1767) (Grotta \& Lunetta 1980; Barreira \& Araújo 2005; Luz \& Boehs 2011); and Tagelus plebeius (Lightfoot, 1786) (Farias \& Rocha-Barreira 2017, Ceuta \& Boehs 2012).

Temperature, salinity, photoperiod and food availability are decisive exogenous factors on reproduction, followed by nutritional reserves, hormonal cycles and genotype (Cáceres-Martinez \& Figueras 1998). External fertilization in bivalves requires synchronization of reproductive activities, resulting in annual cyclical events, associating the environmental variables effects on the reproductive process. The abundant rainfall in the tropical regions and its direct consequences on salinity decrease is the main responsible factor for the environmental heterogeneity at Ceará river estuary. In this context, the rainy season can be considered a natural disturbance, of annual rate, with significant implications for the biology of Phacoides pectinatus. This species has a continuous reproductive cycle, as observed in sympatric bivalves Anomalocardia brasiliana and Tagelus plebeius, These species also have their gonadal development influenced mainly by the salinity variation (Barreira \&; Araújo, 2005; Farias \& Rocha-Barreira, 2017). P. pectinatus population was characterized by larger animals and a spawning peak in the dry season (June to December) and by smaller animals and early gametogenesis in the rainy season (February to May).These results suggest the rainfall role on the population structure of Phacoides pectinatus. This environmental disturbance would be acting on the system as a regulator of the population, contributing to its renewal.

Salinity variations affects the ability at molecular and organic levels to maintain an adequate water balance of the body internal fluids, at any stage of its life cycle (Gilles, 1982). Araújo \& Rocha-Barreira (2004) reported that adult individuals of Anomalocardia brasiliana appear dying during the rainy season due to prolonged osmotic stress, which makes them unsuitable for human consumption. The high rainfall associated with increased freshwater flow from the Ceará river tributaries seems to establish unfavorable conditions (low salinity and turbidity) for older individuals, usually parasitized, and already weakened by the reproductive effort. Natural non-catastrophic disturbances are a regular feature of the environment, so the species present are adapted for the post-disturbance conditions. Such changes have been used to suggest that species become adapted to colonize at different points across the temporal gradient in resources (Platt \& Connell 2003). Thus, the younger and healthier individuals of $P$. pectinatus would have greater survival during the disturbance situation, constituting the next generation of potentially reproductive adults in the immediate season.

Trade-offs between species life history characteristics may be important immediately after environmental conditions have changed as disturbance result (Platt \& Connell 2003). The nutritional reserves are essential for gametogenesis, considering the energy expenditure required for germ cell production (Lunetta \& Grotta 1982). The higher nutrient intake and resuspension of organic material during the disturbance period (rainfall) may be favorable for the filtration feed of P. pectinatus, which at this stage is mostly young and is in initial gametogenesis. However, sediment particles suspension may be an unsuitable condition 
for filtering bivalves. Boehs et al. (2008) observed an Anomalocardia brasiliana densities reduction in Paranaguá Bay (southeastern Brazil) due to osmotic shock and the high water turbidity due to the rainfall rates increased at summer (December to February) and its consequent sudden reduction in salinity. When environmental conditions are unfavorable, the development of the gonads can occur at the expense of nutritious animal reserves (Delfino 2005). Thus, the disturbance caused by rainfall in the estuary would favor gonadal development, with Phacoides pectinatus being in the process of gametogenesis (I + II) during this period. At the end of the rainy season the bivalves would be larger and mature ready to release gametes (IIIA + IIIB + IIIC).

When the disturbance ceases, salinity returns to increase, which is a stimulating factor for spawning (Grotta \& Lunetta 1980, Farias \& Rocha-Barreira 2017). Under great environmental changes, many bivalves respond eliminating gametes and variations in salinity induce the animal cells to osmolality adjustments that influence bivalve reproduction (Barreira \& Araújo 2005).

The rhythm disturbance is defined in terms of its duration, frequency, predictability and severity (Lytle 2001). Different disturbance regimes produce spatial and temporal heterogeneity observed in natural assembly through the differential expression of the life history attributes of the species, in an interdependence relationship (Sousa 1984). Thus, differences in maturation and spawning time may occur as a function of the duration and intensity of the rainy season. This effect was observed when the gonadal development in 2008 and 2009 were compared (Figures 7 and 8). At driest years, Phacoides pectinatus population may be composed by specimens sexually mature or even by greater spawning amounts than at wet years. However, this population should be studied for a large period to confirm this hypothesis. The occurrence of reproductive synchrony between different species in the same region reinforces the influence of environmental variables on the life history of the species. Other bivalves that coexist with $P$. pectinatus also presented reproductive synchrony, such as Tagelus plebeius at the same site of this study (Farias \& Rocha-Barreira 2017) and Anomalocardia brasiliana in other areas of the northeastern Brazil (Narchi 1976, Assis 1978, Barreira \& Araújo 2005).

The Phacoides pectinatus sexual maturation in Bahia state coast (Brazil) was studied by Assis $(1978,1985)$, through macroscopic observation of gonadal development stages. The Bahia populations presented two main periods of spawning, one from April to May and the other from September to December (Assis 1985). However, Delfino (2005), also studying populations from Bahia, did not recognize spawning peaks for this species, but emphasized the predominance of individuals with partially filled gonads, indicating spawning, and the constant presence of immature individuals, evidencing population recruitment along the time. Christo et al. (2016) observed a continuous reproductive cycle of P. pectinatus from the Paraná coast (Southern Brazil). However, these authors verified a period of more expressive gonad repletion in summer (January) when water temperature was higher. In Ceará (present study), this species exhibited the highest spawning peak of October and December 2008, followed by a peak in January 2009.

\section{CONCLUSIONS}

This is the first study on the gonadal development cycle of Phacoides pectinatus in the state of Ceará, northeastern Brazil. We conclude that this population has continuous reproduction, with a predominant gametogenesis in the rainy period and sexually mature 
and spawning in the dry period; and that the increased rainfall, with a consequent decrease in salinity, act as natural disturbance in the estuary, on an annual rate, contributing to the renewal of the population.

Acknowledgements - The authors would like to thank to FUNCAP (Fundação Cearense de Apoio ao Desenvolvimento Científico e Tecnológico) by financial assistance to the development of the project [grant number 263.01.00/09].

\section{REFERENCES}

Aguiar, J.E., Marins, R.V. \& Maia, S.R.R. Copper and Zinc geochemical distribution in bottom sediments from the Ceará- Maranguapinho river estuary. pp. 406-408. In 4th International Symposium on Environmental Geochemistry in Tropical Countries. Brazil. 2004.

Araújo, M.L.R. \& Rocha-Barreira, C.A. Distribuição espacial de Anomalocardia brasiliana (Gmelin, 1791) (Mollusca, Bivalvia, Veneridae) na Praia do Canto da Barra, Fortim, Ceará, Brasil. Boletim Técnico Científico do CEPENE, v.12, p.11-21. 2004

Assis, R.C.F. Anatomia funcional de Phacoides pectinatus (Gmelin, 1791) (Bivalvia: Lucinidae), um subsídio ao conhecimento do ciclo sexual. Tese de doutorado, Universidade de São Paulo. 93p. 1978.

Assis, R.C.F. Maturação Sexual de Phacoides pectinatus (Gmelin, 1791) (Mollusca - Bivalvia). Universitas Ciencia,v. 34, p. 77-92. 1985.

Cárdenas, E.R.B., Aranda, D.A., Sevilla, M.1. \& Espinosa, P.F.R.. Variations in the reproductive cycle of the oyster Crassostrea virginica (Gmelin, 1791), Pueblo Viejo lagoon, Veracruz, México. Transitional Waters Bulletin, v.2, p.37-46. 2007

Barletta, M. \& Costa, M.F. Living and non-living resources exploitation in a tropical semiarid estuary. Journal of Coastal Research, v.56, p.371-375, 2009.

Barreira, C.A.R. \& Araújo, M.L.R. Ciclo reprodutivo de Anomalocardia brasiliana (Gmelin, 1791) (Mollusca, Bivalvia, Veneridae) na praia do Canto da Barra, Fortim, Ceará, Brasil. Boletim do Instituto de Pesca, v.31. p. 9-20, 2005.

Beasley, C.R., Fernandes, C.M., Gomes, C.P., Brito, B.A., Santos, S.M.L. \& Tagliaro, C.H. Molluscan diversity and abundance among coastal habitats of northern Brazil. Ecotropica, v.11, p. 9-20, 2005.

Boehs, G., Absher, T.M. \& Cruz-Kaled, A.C. Ecologia populacional de Anomalocardia brasiliana (Gmelin, 1791) (Bivalvia, veneridae) na Baía de Paranaguá, Paraná, Brasil. Boletim do Instituto de Pesca, v.34, p. 259 - 270. 2008.

Cáceres-Martinez, J. \& Figueras, A. Long-term survey on wild and cultured mussels (Mytilus galloprovincialis Lmk) reproductive cycles in the Ria de Vigo (NW Spain). Aquaculture, v.162, p.141-156. 1998.

Ceuta, L.O. \& Boehs, G. Reproductive cycle of Tagelus plebeius (Mollusca: Bivalvia) in the estuary of the Cachoeira River, Ilhéus, Bahia, Brazil. Brazilian Journal of Biology, v.2, p. 569-576. 2012.

Chesson, P., Gebauer, L.E., Scwinning, S., Huntly, N., Wiegand, K., Ernest, M.S.K., Sher, A., Novoplansky, A. \& Weltzin, J.F. Resource pulses, species interactions, and diversity maintenance in arid and semi-arid environments. Oecologia, v.141, p.236-253. 2004. 
Christo, S.W., Ivachuk, C.S., Ferreira-Júnior, A.L. \& Absher, T.M. Reproductive periods of Phacoides pectinatus (Bivalve; Lucinidae) in the Paranaguá Estuarine Complex, ParanáBrazil. Braz. Jour. Biol., v.76, p.300-306. 2016.

Connell, J.H. Diversity in tropical rain forests and coral reefs. High diversity of trees and corals is maintained only in a noneqilibrium state. Science, v.199, p.1302-1306. 1978.

Darriba, S., Juan, F.S. \& Guerra, A. Reproductive cycle of the razor clam Ensis arcuatus (Jeffreys, 1865) in northwest Spain and its relation to environmental conditions. J. Exp. Mar. Biol. Ecol., v.311, p.101-115. 2004.

Delfino, A.C.S. Estudos Complementares da Dinâmica de População de Phacoides pectinatus (Gmelim, 1791), no Ecossistema de Manguezal de Garapuá - Cairu - Bahia. Monografia de graduação, Universidade Federal da Bahia, Salvador, 65p. 2005.

Farias, M.F.\& Barreira-Rocha, C.A. Ciclo reproductivo de Tagelus plebeius (bivalvia) en el estuario del río Ceará, nordeste do Brasil. Boletim do Instituto de pesca, v.43, n.4, p.578-592, 2017.

Fenchel, T. Ecology: Potencials and limitations. Excellence in Ecology. Germany: Ecology Institute; 185p. 1987.

Gilles, R. Osmoregulatory process in mollusks and crustaceans from media with fluctuating salinity regime. Bol. Fisiol. Animal. USP, v.6, p. 1-36. 1982

Grotta, M. \& Lunetta, J.E. Ciclo sexual de Anomalocardia brasiliana (Gmelin, 1791) do litoral do estado da Paraíba. Rev. Nordest. Biol., v.3, p. 5-55. 1980.

Lucas, A., Beninger, P.G. The use of physiological condition indices in marine bivalve aquaculture. Aquaculture, v.44, p.187-200. 1985.

Lunetta, J.E. \& Grotta, M. Influência dos fatores exógenos e endógenos sobre a reprodução de moluscos marinhos. Bol. Fisiol. Animal, v.6, p.191-204. 1982.

Luz, J.R. \& Boehs, G. Reproductive cycle of Anomalocardia brasiliana (Mollusca: Bivalvia: Veneridae) in the estuary of the Cachoeira River, Ilhéus, Bahia. Braz. J. Biol., v.71, p. 679686. 2011.

Lytle, D.A. Disturbance Regimes and Life-History Evolution. Am. Natur., v.157, p. 525-536. 2001.

Marins, R.V, Paula-Filho, J., Maia, S.R., Lacerda, L.D. \& Marques, W.S. Distribuição de mercúrio total como indicador de poluição urbana e industrial na costa brasileira. Química Nova, v.27, p.763-770. 2004.

Narchi, W. Ciclo anual da gametogênese de Anomalocardia brasiliana (Gmelin, 1791) (Mollusca: Bivalvia). Bol. Zool. USP, v.1, p.331-350. 1976

Penchaszadeh, P.E., Paredes, C. \& Salaya, J.J. Reproductive cycle of the South American scallop Amusium laurenti (Gmelin, 1791) (Bivalvia, Pectinidae). Aquaculture International, v.8, p.227-235. 2000.

Platt, W.J. \& Connell, J.H. Natural disturbances and directional replacement of species. Ecological Monographs, v.73, p.507-522. 2003.

Power, A.J., Nunez, J., Mitchell, M., Walker, R.L. \& Sturmer, L. Reproductive pattern of the blood ark, Anadara ovalis from the northeast coast of Florida. Jour. Shellfish Res., v.23, p.173-178. 2004. 
Rios, E.C. Compendium of Brazilian Sea Shells. 668 p. Evangraf, Rio Grande. 2009.

Rodhouse, P.G., Swinfen, R.C. \& Murray, A.W.A. Life cycle, demography and reproductive investment in the myopsid squid Alloteuthis subbulata. Mar. Ecol., v.45, p.245-253. 1988.

Sousa, W.P. The role of disturbance in natural communities. Ann. Rev. Ecol. Syst., v.15, p. 353-391. 1984.

Stearns, S.C. The evolution of life histories. Oxford: Oxford University Press. 1992.

Vaisman, A.G., Marins, R.V. \& Lacerda, L.D. Characterization of the mangrove oyster, Crassostrea rhizophorae, as a biomonitor for mercury in tropical estuarine systems, northeast Brazil. Bull. Environ. Contam. Toxic., v.74, p.582-588. 2005. 